\title{
Plant genetic effects on soils under climate change
}

\author{
D. G. Fischer - S. K. Chapman • A. T. Classen • \\ C. A. Gehring • K. C. Grady • J. A. Schweitzer • \\ T. G. Whitham
}

Received: 1 April 2013 / Accepted: 5 November 2013 /Published online: 29 November 2013

(C) Springer Science+Business Media Dordrecht 2013

\begin{abstract}
Background In the face of climate change, shifts in genetic structure and composition of terrestrial plant species are occurring worldwide. Because different genotypes of these plant species support different soil biota and soil processes, shifts in genetics are likely to have cascading effects on ecosystems.

Scope We explore plant genetic effects on soil function in the context of climate change, and selection by soils, soil biota and plant-soil feedbacks. We propose categories of genetically-based plant traits that should be prioritized in research on genetic-based effects on soil
\end{abstract}

Responsible Editor: Philippe Hinsinger.

All authors following Fischer DG are in alphabetical order.

D. G. Fischer $(\bowtie)$

The Evergreen State College, 2700 Evergreen Parkway NW, Olympia, WA 98505, USA

e-mail: fischerd@evergreen.edu

\section{S. K. Chapman}

Department of Biological Sciences, Villanova University,

Villanova, PA, USA

e-mail: samantha.chapman@villanova.edu

A. T. Classen · J. A. Schweitzer

Department of Ecology and Evolutionary Biology, University of Tennessee, 569 Dabney Hall, Knoxville, TN 37996, USA

A. T. Classen

e-mail: aclassen@utk.edu

J. A. Schweitzer

e-mail: jen.schweitzer@utk.edu processes including plant productivity and $\mathrm{C}$ allocation, tissue quality, plant water-use, and rhizosphere mutualisms. Additionally, we posit that soil community responses to climate change should be considered in concert with plant genotype because of sensitivity of soil communities to climate. We use two case studies to highlight these points.

Conclusions We argue that the effects of climate change as an agent of selection on plants may cascade to affect soils, and ultimately the structure, composition and function of ecosystems. Understanding the ecological and evolutionary potential of plant-soil linkages may help us

\section{A. Gehring • T. G. Whitham}

Department of Biological Sciences and Merriam-Powell Center for Environmental Research, Northern Arizona

University, Flagstaff, AZ 86011, USA

\author{
C. A. Gehring \\ e-mail: catherine.gehring@nau.edu \\ T. G. Whitham \\ e-mail: thomas.whitham@nau.edu
}

K. C. Grady

School of Forestry and Merriam-Powell Center for

Environmental Research, Northern Arizona University,

Flagstaff, AZ 86011, USA

e-mail: kevin.grady@nau.edu 
understand and mitigate the extended consequences of global change for ecosystems worldwide. Accordingly, we conclude with experimental approaches for examining genetically-based plant-soil interactions across climate change gradients.

Keywords Climate change - Ecosystem processes . Carbon cycling $\cdot$ Nitrogen cycling $\cdot$ Genes to ecosystems . Ecosystem genetics

\section{Introduction}

Predicting and mitigating the impacts of climate change on ecosystems represents one of the greatest challenges in modern ecology. While predicting the impact of climate change on species distributions is receiving much attention (e.g. Thuiller et al. 2008; Aitken et al. 2008; Van der Putten et al. 2010), a less appreciated reality is that climate change can exert selection pressures with consequences for plant population genetic structure and adaptation (Davis et al. 2005; Alsos et al. 2012). In other words, in response to climate change plants may tolerate changes, migrate, go extinct, or adapt, and adaptation represents a particularly important and understudied response (Lavergne et al. 2010). In fact, both shifts in distribution and persistence in-situ by plants may include microevolution as a fundamental response to changing climate (Davis et al. 2005; Norberg et al. 2012). Plant population genetic structure has changed in the past, and is currently changing, in response to variation in climate (Davis et al. 2005; Knight et al. 2006; Parmesan 2006; Travers et al. 2010; Alsos et al. 2012).

The adaptive responses of plants to climate change are intimately coupled with soil communities and soil function because genetic differences among individual genotypes within a plant species may have "extended" consequences for communities and ecosystems, including those belowground (reviews by Whitham et al. 2006, 2012; Hughes et al. 2008; Rowntree et al. 2011; Schweitzer et al. 2012). Though evolutionary impacts on ecosystems are not always established (as reviewed in Fussmann et al. 2007; Matthews et al. 2011; Schoener 2011), plants frequently act as foundation species whose genetic structure and function are important to understand because they create stable conditions that support unique communities of interacting species (Dayton 1972). Further, climate change selection on foundation species (O’Neill et al. 2008; Lavergne et al. 2010) may interact with other niche-based selection processes associated with soil parent material, and soil-plant feedbacks (Fig. 1).

In order to predict future plant-soil connections we must understand how variation in plant genotypic diversity interacts with climate change to influence the function of ecosystems. We predict climate change will act as an agent of selection on foundation species to significantly shape the distribution of plant genotypes, and thus plant-soil interactions that have extended effects on ecosystems, particularly carbon (C) and nitrogen (N) cycling processes in soils. Here, we extend previous reviews on the genetic basis of plant-soil interactions (e.g. Schweitzer et al. 2012), to explore specifically how plant genotypes influence ecosystem processes in the context of evolutionary responses to climate change.

Linkages between plant genetics and soils

The influence of genetic variation in plants on ecosystem $\mathrm{C}$ and $\mathrm{N}$ cycles can be strong and present in a diversity of ecosystems (Schweitzer et al. 2012). For example, plant genotype can affect $\mathrm{N}$ cycling and availability in ecosystems ranging from riparian forests (Schweitzer et al. 2004, 2008a, b, 2011; Fischer et al. 2007, 2010), to oak woodlands (Madritch and Hunter 2002, 2003), to aspen forests (Madritch et al. 2009). The distribution of genotypes that affect nutrient cycles create patterns in soil $\mathrm{N}$ availability that are consistent across geographic distances over 1,000 km, and elevations up to $1,000 \mathrm{~m}$ (Schweitzer et al. 2004; Madritch et al. 2009; Fischer et al. 2010). Studies on ecosystem C dynamics have similarly demonstrated widespread patterns whereby the genetics of foundation plant species strongly influence ecosystem $\mathrm{C}$ uptake and aboveground net primary productivity (ANPP; Crutsinger et al. 2006; Fischer et al. 2006, 2007; Lojewski et al. 2009; Grady et al. 2011), net ecosystem productivity (Souza et al. 2011; Breza et al. 2012), leaf litter decomposition (Schweitzer et al. 2004; Madritch and Hunter 2002; Madritch et al. 2006; LeRoy et al. 2007), soil $\mathrm{CO}_{2}$ efflux (Fischer et al. 2007; Lojewski et al. 2012), and belowground $\mathrm{C}$ allocation (Fischer et al. 2006, 2007; Lojewski et al. 2012) (Fig. 2). While comparisons between these intra-specific effects and inter-specific effects are tempting, (e.g., how do these effects compare with differences among species?), here we emphasize that these genetically-based effects are present in all 


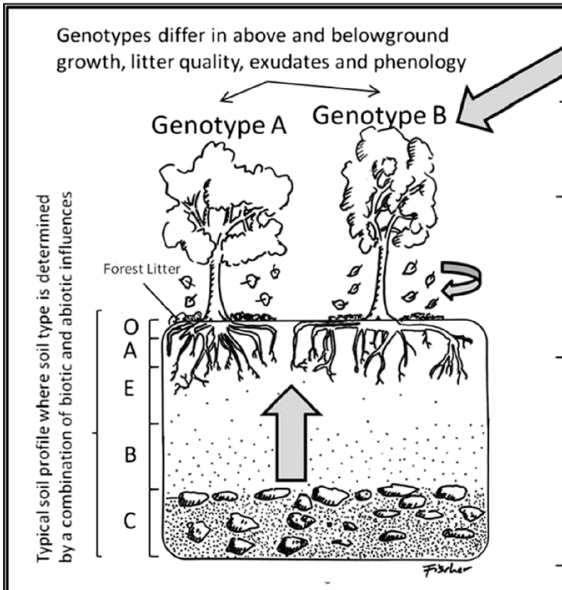

Climate Environment Selection Climate change results in differential genotype survival. Traits that influence soils may be closely, or indirectly related to traits determining survival under climate change

Biotic Environment Selection Organisms above- and belowground (including plant genotypes and their litter inputs) affect nutrient availability, humus accumulation, litter depth, microbial communities, litter depth, microbial communities, and genotype survival and growth

Soil Type Environment Selection Components of soil type determined by climate, relief, parent material, and time provide an additional selection pressure filter for differential genotype survival and growth.

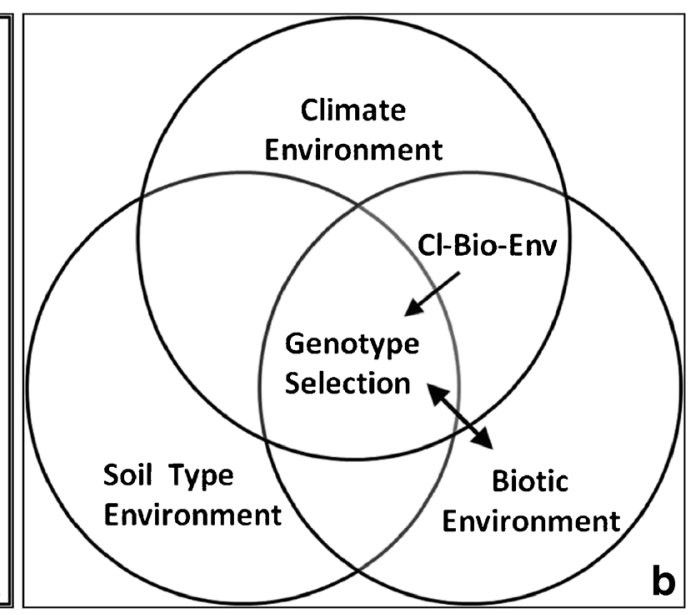

Fig. 1 The interaction among selective effects of climate, soil type and biotic environments results in unique selection on plant genotypes. Recent research emphasizes the interplay between genotype

systems. All populations are genetically variable, and thus all foundation plant species populations are prone to exhibit phenotypic variation that impacts soil communities. The effect of intra-specific variation can be smaller, as large, or larger, than species-level comparisons, the relative importance of which is likely to be context specific (Crutsinger et al. 2009; Schweitzer et al. 2012; Pregitzer et al. 2013). However, the relative importance of intra-specific variation relative to interspecific variation is less important than the specific genetic interactions among plants and their soils, which are common in a diversity of systems (Schweitzer et al. 2012).

These plant genetically-based changes to soils also can create plant-soil feedbacks. In soil manipulation experiments, families and genotypes have shown higher fitness when grown in soils previously conditioned by similar species and genotypes (i.e. positive effects on plant growth and performance can occur when plants are grown in "home" soils). This pattern seems to be related to the fidelity of plant genotypes to the soil microbial communities of individual genotypes that positively "condition" or influence soils for seedlings (Pregitzer et al. 2010; Madritch and Lindroth 2011; Smith et al. 2012; Fig. 3). In contrast, demonstration of negative effects has also been shown (e.g., Liu et al. 2012). These findings suggest that a continuum of feedback responses are possible from "home-field advantage" to "home-field disadvantage", even among closely related individuals. and soil biotic environments, which is unique among selective agents in that the biotic environment may be modified by genotype selection as a result of underlying soil type and climate change

Climate change is already impacting soils and their communities (e.g. Blankenship et al. 2011; Wallenstein and Hall 2011), which may provide new selection pressures on plants via plant-soil feedbacks (e.g. Lau and Lennon 2011; Fig. 1b). Soil biotic communities are essential to $\mathrm{C}$ and $\mathrm{N}$ transformations in soil; thus even small changes in plant-soil-microbe interactions can accrue in the soil system (e.g. by altering $\mathrm{C}$ inputs through NPP) impacting water, $\mathrm{C}$, or N cycles over time. Genetically-based soil microbial interactions may buffer plants against climatic change and allow species persistence (through differential survival of genotypes; Van der Putten et al. 2013). For example, microbial communities may enhance water relations and thus plant persistence through periods of drought (Lehto and Zwiazek 2011; Augé 2004; Lau and Lennon 2012; case study below). Similarly, plant-microbe interactions may regulate nutrient cycling with effects on plant performance, enhancing persistence in the face of climate change. Of course, negative effects on plants resulting from microbial responses to climate change may also be genetically specific, but little is known about these responses.

Here, we propose that the direct influence of climate change on genetically-mediated plant-soil interactions has two components: (1) the nature of the plant traits that are selected for under climate change scenarios (Fig. 1a; Climate Environment Selection), and (2) the nature of independent climate change effects on soil community composition and function (Cl-Bio-Env; Fig. 1b). Different plant genotypes exhibit traits that impact soil 

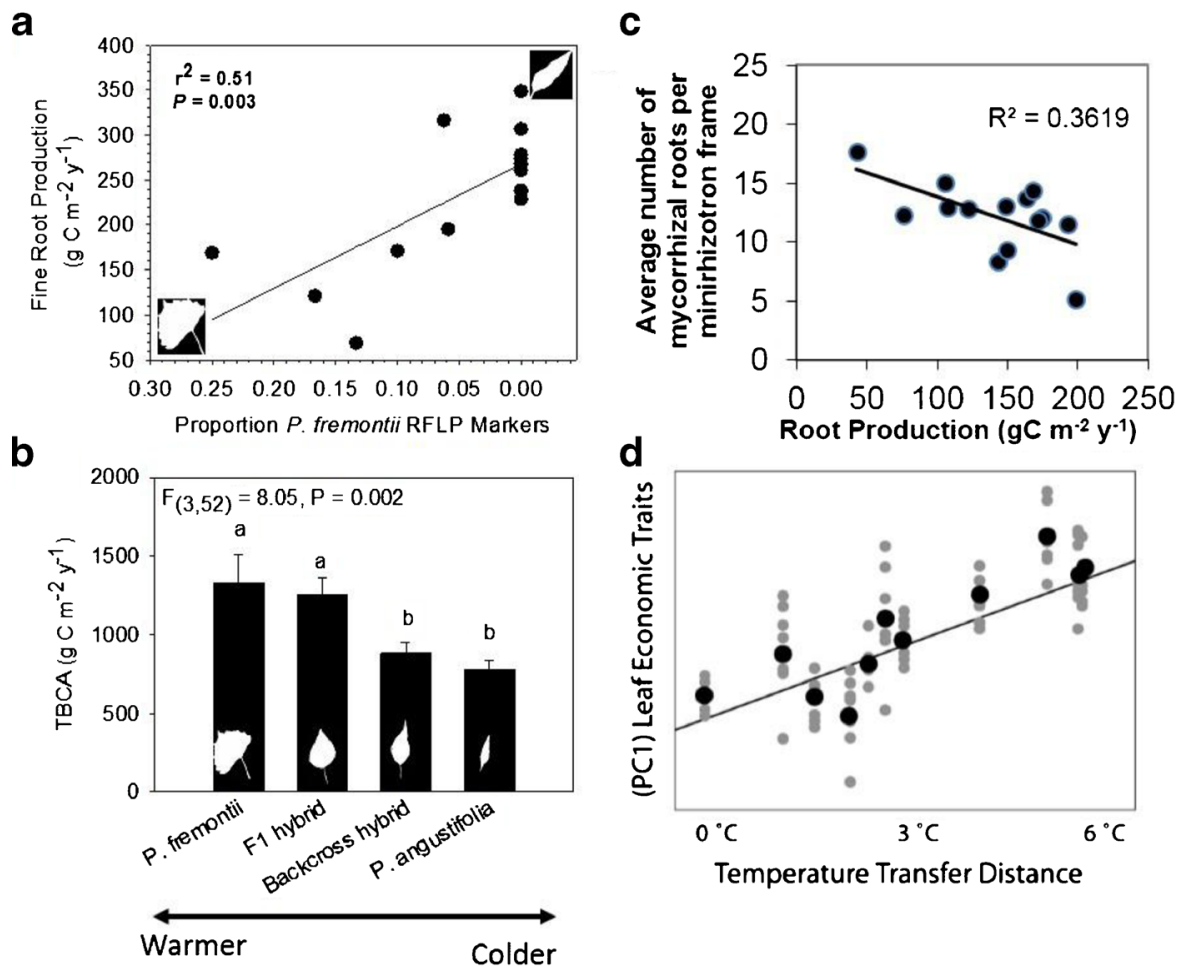

Fig. 2 Key traits that directly affect soils are variable by genotype origin, and temperature of origin in the Populus system across a hybridization gradient (a-c), and intraspecific genetic (d) gradients. Panels a-b represent an identical gradient from low elevation (warm) climate tree types (on the left) to high elevation (cold) climate trees (right). Trees from colder locations have higher fine root production even when grown in the same climate conditions (a; after Fischer et al. 2006, 2007). Inversely (b; also after Fischer et al. 2007), warmer climate trees have higher total belowground carbon allocation (TBCA) in common garden environments, suggesting selection may favor high belowground $\mathrm{C}$ allocation, even

processes and feedbacks, but because plant genotype and soil communities interact, soil community responses to climate change may also mediate plant responses. We explore these points in the following sections followed by case studies that illustrate plant genotypic interactions with climate, soil communities, and soil processes in two natural ecosystems.

\section{Plant traits and soils}

We focus here on plant traits that might be affected by in-situ selection acting on pre-existing patterns of plant genetic variation across the landscape. Changes in plant phenotypic plasticity, demography, and distribution/migration are clearly

when it results in lower root growth. Error bars represent + one standard error. c High root production genotypes also have lower visible observable ectomycorhizal roots in minirhizotron frames (Fischer et al. unpublished data, based on Fischer et al. 2007). Finally, d multivariate leaf physiological (economic) traits represented by a principle components analysis axis score vary predictably with degree of climate change in intraspecific assisted migration experiments with the species $P$. fremontii (after Grady et al. 2013). Such multivariate trait differences may have proportional, and sometimes re-enforcing effects on soil communities and soil function

important responses to climate change (Lavergne et al. 2010), but are beyond the scope of the current review. Similarly, the subjects of climate-based selection on plant traits and plant trait distributions have been reviewed recently (e.g. Lavergne et al. 2010; Churma et al. 2011) and are beyond the scope of this paper. Our goals instead, are to (1) identify key traits that link plants to soils through genetically variable mechanisms, and (2) explore the consequences of this multivariate array of genetically-based traits linking plants and soils in a climate change context. Table 1 provides a heuristic framework demonstrating some potential interactions between effects of selection on traits, consequences for ecosystem processes and soil communities, and the combined multivariate effects of selection acting on multiple traits. Within this table, we provide some 
Fig. 3 Plant-soil feedbacks are likely to be fundamental to plant responses to changing climate. Panels (a) and (b) indicate that geneticbased conditioning of soils leads to variable expression of plant traits in common environments. Seedling families (a) of Populus angustifolia have the lowest mortality and highest growth (height) when growing in soils previously conditioned by $P$. angustifolia trees, even though these soils were less fertile overall $(F=18.75, p<$ $0.001)$. Each line represents the mean height of each family growing in each soil type; the blue symbols indicate mean values. Seedlings collected from individual $P$. angustifolia genotypes (b) overall grew taller when grown in their maternal soil rather than a soil conditioned by other individuals ( $t=1.98$, $p=0.05$ ). Each line represents the growth (height) response of each individual tree growing in each soil type; blue symbols indicate mean responses. In both studies shifts in the soil microbial communities were the putative mechanisms for the positive feedbacks. Data modified from Pregitzer et al. (2010) and Smith et al. (2012), respectively. Error bars represent \pm one standard error
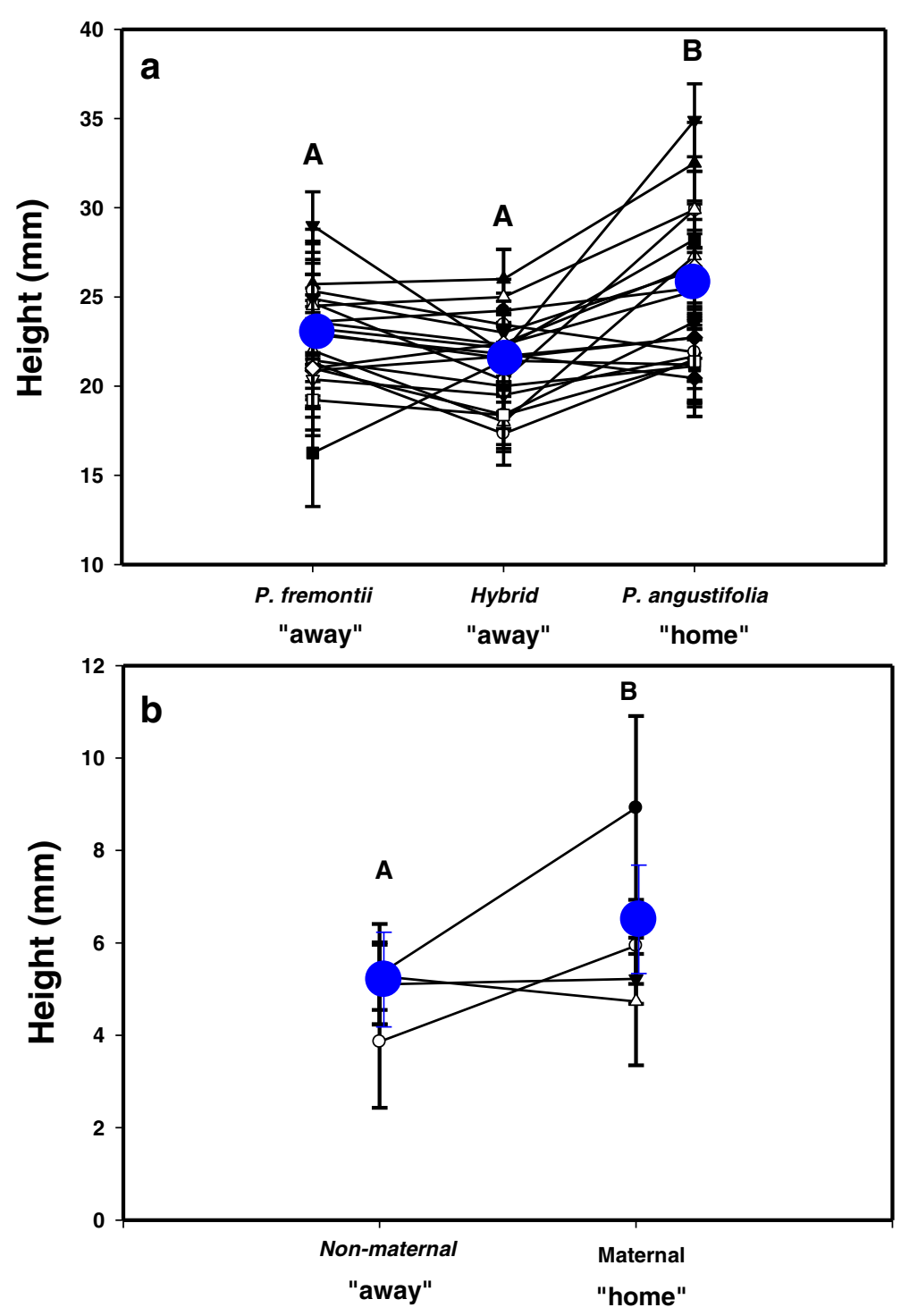

Soil Origin generalized potential responses of plant traits to specific climate change factors based on either reviews (Horton and Hart 1998; Bellgard and Williams 2011; Churma et al. 2011; Norby and Zak 2011; Bardgett et al. 2013; Keenan et al. 2013) or inferred general understanding of plant responses to temperature, soil moisture, and increased $\mathrm{CO}_{2}$ (assuming that the basic physiological responses to these factors also represent traits favored by directional selection). These responses are provided here not as a set of predictions, but rather for the heuristic purpose of visualizing how multiple plant traits interact and affect ecosystem function and communities in a climate change framework. The specific selection effects of climate change on ecosystem processes are not completely understood (Fussmann et al. 2007; Matthews et al. 2011; Schoener 2011), yet it is clear that shifting climate may result in different outcomes for different plant traits, with correspondingly diverse consequences for plant effects on soils. For example, in the table (Table 1) a combination of higher temperatures, reduced precipitation, longer growing seasons, and higher $\mathrm{CO}_{2}$ have a combined effect on plant water use that might be characterized as a strong negative effect (the selection impact of all changes might be for lower 
Table 1 Theoretical framework for climate change selection on key genetically heritable plant traits with hypothetical consequences for ecosystems processes and soil communities

\begin{tabular}{|c|c|c|c|c|c|c|c|}
\hline $\begin{array}{l}+=\text { increase } \\
-=\text { decrease } \\
\mathrm{n}=\text { neutral or unknown effect } \\
\text { Climate change selection pressure }\end{array}$ & $\mathrm{NPP}_{1,2}$ & $\begin{array}{l}\text { Belowground C } \\
\text { allocation } \\
1,2\end{array}$ & $\begin{array}{l}\text { Leaf and root } \\
\quad \text { litter quality }\end{array}$ & $\begin{array}{l}\text { Plant water- } \\
\text { use }_{3}\end{array}$ & $\begin{array}{l}\text { Hydraulic } \\
\text { lift }_{3}\end{array}$ & $\begin{array}{l}\text { Rhizosphere } \\
\text { mutualisms }\end{array}$ & \\
\hline Higher temperatures & $\mathrm{n}$ & + & - & - & + & + & \\
\hline Reduced precipitation & - & + & - & - & + & + & \\
\hline Longer growing season & + & + & $\mathrm{n}$ & - & $\mathrm{n}$ & $\mathrm{n}$ & \\
\hline $\mathrm{High} \mathrm{CO}_{2}$ & + & + & - & - & $\mathrm{n}$ & + & \\
\hline Net climate change selection pressure & Mild + & Strong + & Strong - & Strong - & Mild + & Strong + & \\
\hline \multicolumn{8}{|c|}{ Consequence of net selection effect on soil communities } \\
\hline Bacterial communities $^{\mathrm{b}}$ & + & + & - & + & + & + & \\
\hline Mycorrhizal communities ${ }^{c}$ & + & + & + & $\mathrm{n}$ & + & + & \\
\hline \multicolumn{7}{|c|}{ Consequence of net selection effect on ecosystem process } & Net effect \\
\hline Carbon sequestration $^{\mathrm{d}}$ & + & + & + & $\mathrm{n}$ & + & + & $+(5 / 6)$ \\
\hline Organic matter decomposition ${ }^{\mathrm{e}}$ & $\mathrm{n}$ & + & - & + & + & $\mathrm{n}$ & $\mathrm{n}(+3 / 6)$ \\
\hline Soil nutrient availability $(\mathrm{N} \text { and } \mathrm{P})^{\mathrm{f}}$ & + & + & - & + & + & + & $+(5 / 6)$ \\
\hline Ecosystem transpiration ${ }^{\mathrm{g}}$ & + & + & $\mathrm{n}$ & - & + & + & $+(4 / 6)$ \\
\hline
\end{tabular}

${ }^{a}$ Directional responses given here are heuristic only, based on dynamics discussed in references indicated by the numerical subscripts associated with each trait: 1: Fischer et al. 2007; Norby and Zak 2011; Churma et al. 2011; 2: Bardgett et al. 2013; 3: Keenan et al. 2013; Horton and Hart 1998: and 4: Bellgard and Williams 2011

${ }^{\mathrm{b}}$ Bacterial communities may benefit from increased belowground allocation, organic matter production, and hydraulic redistribution increasing soil moisture. Reductions in litter quality might reduce microbial biomass. Very little is known about the nature of these responses

${ }^{\mathrm{c}}$ Mycorrhizal communities may benefit from increased belowground allocation, organic matter production, and hydraulic redistribution. Reductions in plant water-use might reduce mycorrhizae, or increase reliance on mycorrhizal symbionts. Very little is known about the nature of these responses

${ }^{\mathrm{d}}$ Carbon $(\mathrm{C})$ sequestration, realized as the result of $\mathrm{C}$ inputs through photosynthesis and losses through respiration and later transfer of $\mathrm{C}$ into and out of the ecosystem. In this example, selection effects might universally increase $\mathrm{C}$ sequestration except in the case of mildly reduced water-use traits, which have unknown effects

${ }^{\mathrm{e}}$ Organic matter decomposition might be positively affected by selection changes that result in higher belowground $\mathrm{C}$ allocation, less plant water-use, and increased hydraulic redistribution. Lower litter quality might decrease organic matter decomposition, and increased aboveground growth and belowground mutualisms have unknown effects

${ }^{\mathrm{f}}$ Soil nutrient availability might be universally increased by the complementary net effects of multiple traits affected by climate change selection pressures in this example, but these effects may be "attenuated" by reductions in litter quality which reduce nutrient cycling rates

${ }^{\mathrm{g}}$ Higher aboveground growth, belowground growth, hydraulic redistribution and belowground mutualisms all can be associated with increased ecosystem transpiration. Nevertheless, selection for more water-use efficient genotypes may attenuate the effects of other traits

plant water use). Reduced plant water-use might result in higher soil moisture (in this hypothetical example) and thus increase bacterial communities (Schimel et al. 2007), but have unknown effects on mycorrhizal communities (Bellgard and Williams 2011). This would have unpredictable impacts on carbon sequestration, but probably increase organic matter decomposition, soil nutrient availability, and reduce ecosystem transpiration. Nevertheless, since other traits are being affected by climate too, the net effect on ecosystem processes might be positive for carbon sequestration, nutrient availability, and ecosystem transpiration, but idiosyncratic for organic matter decomposition (primarily because drought might select for plants with lower litter quality).

\section{Effects of genetically-based plant traits on soils}

Multiple plant functional traits are affected by any selection event or genetic change within a population, but some traits are more likely than others to have strong effects at the plant-soil interface (for a theoretical 
framework see Table 1). We propose that there are four central categories of genetically-based traits that are essential to understand climate change impacts on plant-soil relationships: (1) net primary productivity (NPP) and belowground C allocation; (2) leaf and root chemistry; (3) plant water-use, and (4) plant rhizosphere-microbial symbioses.

Genetically-based variation in NPP and C allocation in plants is relatively well studied (Madritch and Hunter 2002, 2003; Schweitzer et al. 2004; Crutsinger et al. 2006; Hughes and Stachowicz 2009; Fischer et al. 2006, 2007; Lojewski et al. 2009, 2012; Avolio et al. 2013). Such variation in plant $\mathrm{C}$ dynamics influences soil development and soil $\mathrm{C}$ accumulation via a direct influence on $C$ inputs to the soil (Rasse et al. 2005). Root inputs in particular are now recognized as a major driver of soil C storage. Plants, via soil organic matter inputs, alter soil cation exchange capacity, bulk density, soil $\mathrm{pH}$, microbial community structure, and hydraulic properties - all fundamental components of soil structure and function (Zinke 1962). Thus, genetic variation that affects $\mathrm{C}$ allocation can have consequences for the entire plant-soil system. Climate change is shaping species responses in terms of $\mathrm{C}$ flux in a wide range of ecosystems (e.g. Asner et al. 2003; Sharp et al. 2013). For example, plants are allocating $\mathrm{C}$ to roots at deeper soil profiles under elevated atmospheric $\left[\mathrm{CO}_{2}\right]$ in forested ecosystems possibly leading to a shift in soil development, root morphology and C storage (Norby and Zak 2011). Specifically, selection could result in genotypes that invest more productivity belowground, increasing ecosystem $\mathrm{C}$ storage. Given that foundation plant species have substantial genetically-based variation in belowground $\mathrm{C}$ and allocation traits, evolutionary responses to climate change may alter soil traits associated with plant $\mathrm{C}$ inputs. A related trait category is the timing of $\mathrm{C}$ inputs and allocation to soils. Recent reviews highlight that leaf and rooting phenology have genetic bases that are sensitive to climate change where climate changes may select for genotypes with altered timing of leaf-out and rooting phenology compared to current populations (Wilczek et al. 2010). Such phenological shifts likely have consequences for soil C dynamics (Bardgett et al. 2013).

Second, leaf and root chemical traits directly affect tissue decomposition, nutrient turnover and soil nutrient status (Binkley and Giardina 1998). In particular, secondary plant compounds such as condensed tannins vary among genotypes, although their expression is influenced by the environment (i.e. many secondary compounds are inducible or can be up- or downregulated based on environment). Because these compounds are an important pathway through which plant litter decomposition and $\mathrm{N}$ mineralization are affected, these higher level effects of genes are referred to as community and ecosystem phenotypes (Schweitzer et al. 2004, 2008a, b; LeRoy et al. 2007; Iason et al. 2012). Similarly, genetically linked changes in plant $\mathrm{C}: \mathrm{N}$ ratios, lignin, $\mathrm{N}$, and $\mathrm{P}$ concentrations are correlated with both litter decomposition and nutrient availability at the plant-soil interface (e.g., Treseder and Vitousek 2001; Schweitzer et al. 2004; Chapman et al. 2006a; Fischer et al. 2010). Root chemical quality, in particular $\mathrm{N}$ concentration, can influence root litter decomposition and nutrient release to soils (e.g., Classen et al. 2007). Because roots are embedded in soils and root inputs are known to be especially important in regulating soil $\mathrm{C}$ accumulation (Rasse et al. 2005), genetically-based differences in root chemical quality and exudates should be an important future focus of research.

Third, plant water-use represents a trait pathway that impacts soils due to its direct effect on soil moisture status and hydraulic lift (Horton and Hart 1998). Whole plant water-use can vary among genotypes and across diverse taxa, with implications for ecosystem function (as reviewed in Fischer et al. 2004). For instance, where climate change results in increasing aridity, selection may favor genotypes with lower water-use (Grady et al. 2013), and such altered water-use strategies could reduce hydraulic lift and surface soil moisture (Horton and Hart 1998). Since soil moisture has direct effects on microbial activity and ecosystem processes, this trait modification directly affects soil biota and soil processes.

Fourth, of the above categories, the least understood are microbial symbioses and rhizosphere communities (those within $2 \mathrm{~mm}$ of root surfaces) in natural communities (Schweitzer et al. 2012; Hoeksema and Classen 2012). Though not a true "trait", symbiotic soil microbial communities often act like traditional plant traits. Several studies in natural, model, and managed systems now show that intraspecific genetic variation influences rhizosphere microbial community composition (Bressan et al. 2009; Micallef et al. 2009; Weinert et al. 2011; Lundberg et al. 2012; Zancarini et al. 2012; Peiffer et al. 2013). In some cases, these community changes are associated with relatively small changes in root traits and likely numbers of genes (e.g., Bressan et al. 2009; Lankau 2011), though recent studies indicate that most 
traits are controlled by many genes (Mackay et al. 2009). A recently discovered quantitative trait locus (QTL) in Populus spp affects ectomycorrhizal symbiosis (Labbe et al. 2011), suggesting sensitivity of belowground symbioses to tree genetics similar to traditional plant traits such as productivity, chemistry, and wateruse. Similar sensitivity of other components of the rhizosphere community to plant genetic variation remain understudied in natural systems, but are important to consider since climate change factors which favor higher belowground $\mathrm{C}$ allocation (e.g., drought, high atmospheric $\mathrm{CO}_{2}$ ) are likely to favor genotypes with higher investment in rhizosphere symbioses (e.g., Table 1).

Multiple traits determine how genetics influence soils

Emphasis on the underlying genetics of key traits, tradeoffs among these traits, and interactions among traits may allow us to better understand and mitigate plant responses to climate change. For example, genotypes should vary in the traits outlined above based on the specific environments where they are selected to grow (Soil Type and Climate Selection; Fig. 1a, b; Chapin 1980). Nevertheless, the multivariate combination of these plant genotype traits will ultimately determine plant genetic effects on soils (see case studies below; Table 1). While it is not a new concept that multiple traits simultaneously affect soils, with advances in molecular and quantitative genetics combined with field trials in different environments we have the potential to understand their genetic basis and interactions as never before. For example, the trait categories outlined above could have simultaneous effects on the soil community and soil processes (Table 1). Accordingly, when the combined traits have complementary effects on soil communities and soil processes (e.g. soil $\mathrm{C}$ and $\mathrm{N}$ cycling), soil communities and processes may have high fidelity to individual genotypes. For example, increased leaf litter quality (e.g., low C:N) and high hydraulic lift (resulting in high soil moisture) may interact to result in high litter decomposition and soil $\mathrm{CO}_{2}$ efflux rates under a specific genotype's crown. In this way, leaf litter quality and plant water use are complementary in their effects, and could result in an "amplified" effect of plant genotype on soil processes. Similarly, other traits may have opposing effects on soil processes, and might be considered to be "attenuated" effects of the genotype. Because combinations of plant traits will influence plant effects on soils in a modified climate, analyses of multiple interacting traits are critical to predict the response of the integrated plant-soil systems to climate change.

Geographical patterns of intraspecific traits

Geographical position of plants within a species distribution may affect trait-based responses to climate change (Hardie and Hutchings 2010; Wang et al. 2010; Fournier-Level et al. 2011; Hancock et al. 2011). For instance, for some northern latitude species such as Pinus and Larix species growth is expected to decrease on the warm edge (either southern or low elevation locations) of their distribution, but increase on the cold edge (northern or high elevation locations; Rehfeldt et al. 1999; Wang et al. 2010). Similarly, populations are known to differ in local adaptation and genetic variation at the core versus the margins of a species' distribution due to gene flow and local climate niche-based selection processes (Hardie and Hutchings 2010; Fournier-Level et al. 2011). For example Solidago genotypes from northern and southern parts of their ranges differ in their ability to tolerate heat stress, and low genetically-based variation in heat-tolerance in northern populations may lead to a reduction in their ability to respond to warming in the future (Souza et al. 2011; Breza et al. 2012). Differential adaptation to changing temperatures among leading and trailing populations is an example of climate environment selection (Fig. 1a), a niche-based selection process that will interact with the soil environment and plant-soil feedbacks. Trailing and leading edges of populations can differ in key traits, and these traits are likely linked to plant stress, productivity and $\mathrm{C}$ allocation, tissue quality, water-use strategies, and rhizosphere communities - all of which can influence soil function and feedback to the plant. Gene flow from the core of a species range to both the leading and trailing edges of that range may also provide a mechanism for affecting traits selected by changing climate, particularly when those traits are adaptive under new climate conditions (Sexton et al. 2011; Norberg et al. 2012).

\section{Soil community responses to climate change affect plant-soil feedbacks}

Independent climate-mediated changes in soil communities and function can feed back to impact plant performance and evolution. Soil biota across a diversity of 
ecosystems are often sensitive to global change factors including changes in temperature, precipitation and elevated atmospheric $\mathrm{CO}_{2}$ concentrations (e.g., Antoninka et al. 2009; Castro et al. 2010; Gray et al. 2011). Recent evidence indicates that tolerance or acclimation is possible for soil bacteria and widespread groups of fungi in response to changes in temperature and soil moisture (Evans and Wallenstein 2012; Crowther and Bradford 2013). Plants provide $C$ to soil communities and soil communities mineralize nutrients, thus plant and soil communities can be tightly linked (Binkley and Giardina 1998). How soil communities respond to climate change has consequences for plant fitness and performance (Fig. 1b), as soil biota directly and indirectly mediate soil nutrient dynamics and plant uptake as well as mediate plant-soil linkages and feedbacks (Kardol et al. 2010). While changes to soil communities have large roles in mediating plant response to climate change, little is understood about how plant genotype by soil community interactions affect plant evolutionary response to changing environmental conditions. Resource availability as well as community interactions will determine the strength of plant-soil interactions, and both can be influenced by the genetics of the foundation plant species (e.g. Pregitzer et al. 2010; Zancarini et al. 2012). Here, we highlight recent studies showing how microbial communities and plants might interact under climate change scenarios and how plant genotypes can modify soil communities.

Climate induced shifts in decomposing and mineralizing soil organisms or pathogens may alter the function of the soil community, soil $\mathrm{C}$ inputs and decomposition processes and feedback to alter plant performance. For example, a direct temperature induced shift in microorganisms may alter plant growth, or shift root-derived $\mathrm{C}$ inputs by releasing specific microbial metabolites that affect root exudation and growth (e.g., as reviewed in Bardgett et al. 2013). Moreover, legacy effects of plant and soil communities may accumulate, reach thresholds, or cause longer-term switches in landscape patterns. For example, in a warming experiment across an arid grassland elevation gradient in Northern Arizona, Wu et al. (2012) found that long-term feedbacks involving soil microbial communities and $\mathrm{N}$ cycling ultimately resulted in plant species replacement, overriding initial responses of plants to warming. These plant community shifts can influence the trajectory (e.g. succession) as well as the ecosystem response (e.g. $\mathrm{C}$ accrual) to climatic change over time.

Plant interactions with soil communities may allow plants to tolerate novel environments. For example, in a multi-generational feedback experiment with plants and soil microbial communities, Lau and Lennon (2012) found that plant fitness was contingent not on plant adaptations to altered conditions, but to associations with more rapidly evolving drought- or mesic-adapted soil communities. After three generations, the rapid responses of soil communities to altered conditions enhanced plant fitness when both conditioned and naïve plants were grown with the microbial community that best matched the environmental conditions (i.e., drought adapted soil communities led to enhanced plant fitness under drought conditions). Moreover, mycorrhizal fungi are known to convey plant resistance to extreme events potentially increasing plant genotype persistence under a changing climate (Bellgard and Williams 2011; Hoeksema and Classen 2012). For example, mycorrhizal fungi can convey plant tolerance to drought, and thus drought resistant genotypemycorrhizal pairs are likely to persist as drought-prone ecosystems dry under climatic change (e.g. Kipfer et al. 2012).

Mycorrhizal fungi also play an important role in regulating soil function, and so both climate and plantgenetic effects on mycorrhizal colonization and composition have important consequences for soil-based ecosystem processes. Mycorrhizal fungi can play important roles in soil respiration (Heinemeyer et al. 2007) and decomposition (Langley et al. 2006), as well as C and N cycling (Cornelissen et al. 2001; Chapman et al. 2006b; Courty et al. 2010). Individual plant genotypes can have distinct mycorrhizal fungal communities (Velmala et al. 2013) that may have extended consequences for soil $\mathrm{C}$ and N cycling (Hoeksema and Classen 2012). In a study of Populus sp. genotypes that varied in ectomycorrhizal colonization, Courty et al. (2010) found that different plant genotypes exhibited varying production of enzymes important to the liberation of soil $\mathrm{C}$ and $\mathrm{N}$ from organic matter, potentially generating new feedbacks to future plant colonists.

In addition to direct impacts of climate change on soil communities and individual plant genotypes, biotic interactions among plants and the soil community (van der Putten et al. 2010, 2013) may differentially affect genotype performance. In a series of field and greenhouse experiments at the northern edge of forest species 
ranges, McCarthy-Neumann and Ibanez (2012) found that tree species had higher fitness outside of their normal range because they were able to "escape" from pathogen accumulation in the soil that reduced their fitness in the home environment. These examples with both mycorrhizal fungi and pathogens, coupled with the new research highlighted above, lead us to propose that the selective environment (positive and negative) imposed by soil communities may be fundamental in determining plant genotype success, which may in-turn affect soil communities. These effects of plant genotype on soil communities may be manifested through changes in plant productivity, C allocation, tissue quality, water-use patterns, and interactions with other rhizospheric community members.

\section{Two case studies}

Here, we present data from two long-term study systems. While no single case study can be reflective of all systems, an understanding of evolutionary impacts on ecosystem process is far from complete in any system, these case studies help identify key commonalities where climate factors interact with foundation species genetic variation and plant-soil interactions. In both cases, gene by environment $(\mathrm{G} \times \mathrm{E})$ interactions have shaped soil processes across ecosystems as a result of climatic changes, soil types, and soil communities interacting with plant genotypes (Fig. 1a, b). These studies illustrate why a framework that includes multiple selection effects (climate, soil, and biotic environment selection), combined with an interactive approach to genetically-based plant traits (e.g., the trait categories outlined above), is essential for predicting the outcome of climate mediated influences on ecosystems.

Plant-soil linkages along elevation gradients in Populus riparian forests

Populus spp. (cottonwoods) are important riparian trees in the American southwest where they perform a foundational role influencing community structure, biodiversity and ecosystem function, even though the riparian habitat they occupy is small in this arid environment (Naiman and Décamps 1997; Whitham et al. 2006). Because Populus spp. are phreatophytes (plants which have roots in constant contact with ground water) within a riparian habitat, soil-type environmental selection
(Fig. 1) for these trees is relatively simple - they often grow only on entisols along major streams and rivers. However, climate environment and biological environment selection (Fig. 1) can be much more complex (also see Wullschleger et al. 2009).

Using field studies along an elevation gradient coupled with extensive common garden experiments to determine the selective influence of elevation on traits, Fischer et al. (2006, 2007), and Lojewski et al. (2009, 2012), found predictable genetically determined patterns in fine root production, belowground $\mathrm{C}$ allocation, and soil C flux (Fig. 2). Specifically, warmer, more productive environments at lower elevations contained genotypes that grew more quickly aboveground, and less belowground than genotypes from cooler environments, even when planted in the same environment (Fischer et al. 2007; Lojewski et al. 2012). Higher C allocation belowground in low elevation genotypes was associated with higher soil $\mathrm{CO}_{2}$ efflux, and lower investment in tree roots both in the field and in a common garden (Fig. 2). Thus higher $\mathrm{C}$ allocation belowground did not necessarily result in higher belowground $\mathrm{C}$ in soils. Collectively this work might suggest increasing temperatures would be associated with genotypes that reduce $\mathrm{C}$ storage in soils. Higher root production was also negatively associated with numbers of ectomycorrhizal roots identified in minirhizotron observation tubes (Fig. 2; Fischer et al. unpublished data), though mycorrhizal communities in this gradient are clearly determined by both environmental and genetic factors (Gehring et al. 2006, unpublished data).

Other studies along an elevation gradient of the same Populus forests found that genotypes from lowelevation warm environments had lower foliar condensed tannin concentrations, faster leaf decomposition, and higher soil $\mathrm{N}$-mineralization, then genotypes from cold, high elevation environments (Schweitzer et al. 2004, 2008b; Rehill et al. 2006; LeRoy et al. 2007). These findings are consistent with more generally observed patterns across species where litter decomposition is faster in resource rich environments (Chapin 1980). Foliar leaf chemistry can be highly heritable, an important prerequisite for adaptive evolution (Bailey et al. 2006; Grady et al. 2013). Variation in plant genetics also impacts $\mathrm{N}$ transformation and microbial communities in soils (Schweitzer et al. 2004, 2008a, b, 2012) suggesting strong plant-soil feedbacks (Fig. 3; as discussed above). Together, these studies suggest that lower elevation, warmer environments select for trees 
with fast resource turnover, high substrate quality, and acquisitive traits that promote fast growth (Fischer et al. 2007; Lojewski et al. 2009). In this case, leaf recalcitrance traits are complementary to the effects of increased root production in cold climate genotypes discussed above (Fischer et al. 2006), resulting in potential amplified effects of the genotype on $\mathrm{C}$ and $\mathrm{N}$ cycling rates in this system.

Studies using Populus fremontii in a common garden planted in one of the hottest environments in the world (Lower Colorado River, AZ; maximum temperatures $>52{ }^{\circ} \mathrm{C}$; the thermal maximum for the species) show a different pattern. Genotypes were collected from across the range of $P$. fremontii, and grown in a single warm common garden. Trees from the warmest thermal environments express heritable leaf traits with high leaf $\mathrm{C}: \mathrm{N}$, low $\mathrm{N}$, low specific leaf area, and higher whole-tree productivity (Grady et al. 2011, 2013; Fig. 2). Selection of these warm-adapted genotypes could impact soils through reduced decomposition and nutrient transformation rates, suggesting a different outcome of selection at the trailing edge of a species' distribution. These examples indicate that multiple traits, potentially reflecting climate selection, vary along elevation gradients, with extended and variable consequences for soil processes. In this example, the holistic effect of plant genotype on soil communities and biota is only understandable in the light of the combined effect of plant traits related to productivity, C allocation, and tissue quality (Fig. 2), all of which may be subject to climate environment selection and plant-soil feedbacks.

Drought-tree interactions and piñon-juniper woodlands

Increasing drought severity and frequency associated with climate change may lead to increased mortality of genotypes already at their physiological water stress threshold in arid and semi-arid regions (Gitlin et al. 2006; McDowell et al. 2008). These mortality events could lead to changes in both the genetic structure (e.g. which genotypes survive) and function (e.g. feedbacks to $\mathrm{C}$ and $\mathrm{N}$ cycles) of arid and semi-arid ecosystems. Regeneration and recruitment of foundation species may be similarly affected (Gitlin et al. 2006; Lloret et al. 2009).

Long-term studies in a piñon-juniper woodland show the importance of plant genotype, climate, and herbivore interactions on soil biota and soil processes. Piñon
(Pinus edulis) in this area differ in their geneticallybased resistance to herbivory by the moth, Dioryctria albovittella, and the expression of susceptible and resistant phenotypes can be stress-induced (Mopper et al. 1991). When susceptible and resistant trees grow in relatively water and nutrient-rich sandy loam soils, their phenotypes are similar; however when they grow in nutrient and water-limited cinder soils, moth herbivory of susceptible trees results in distinct architectural phenotypes (See Fig. 4). Because of their impacts on the tree, susceptibility and resistance to herbivory has cascading impacts on the bulk soil microbial community and their ectomycorrhizal fungal mutualists (Gehring and Whitham 1991; Classen et al. 2006; Classen et al. 2007). In the absence of drought, chronic moth herbivory on susceptible genotypes reduces plant growth (Whitham and Mopper 1985), alters the abundance of ectomycorrhizal fungi (Gehring and Whitham 1991) and alters the abundance and diversity of other soil biota (Classen et al. 2006, 2007). Further, litter and root decomposition and nutrient cycling can differ among susceptible and resistant genotypes (Chapman et al. 2003; Classen et al. 2007).

Over the last 17 years, piñon-juniper woodlands have experienced dry conditions, punctuated by two extreme drought years (1996 and 2002) that resulted in high piñon mortality across the southwestern United States (Mueller et al. 2005; Breshears et al. 2008; Garrity et al. 2013). Most importantly, drought was an evolutionary event where differential mortality of moth susceptible (21\% mortality) versus resistant trees (68\% mortality) has altered the genetic structure and function of this ecosystem (Sthultz et al. 2009a; Gehring et al. unpublished data). Seedlings derived from these same trees show similar drought tolerance as their mothers, suggesting potential heritability of drought tolerance (Sthultz et al. 2009a). In addition, the ectomycorrhizal fungal communities of moth resistant and susceptible trees are distinct; susceptible trees are dominated by a single genus of ascomycete fungi while resistant trees have much higher abundance of basidiomycete fungi (Sthultz et al. 2009b). Long-term moth removal experiments demonstrate that these differences in the ectomycorrhizal community are due to plant genetics rather than an indirect effect of moth herbivory (Sthultz et al. 2009a, b). Thus, the differences in ectomycorrhizal fungal species composition are strongly tied to the differences in the drought tolerance of their host plants. 
a

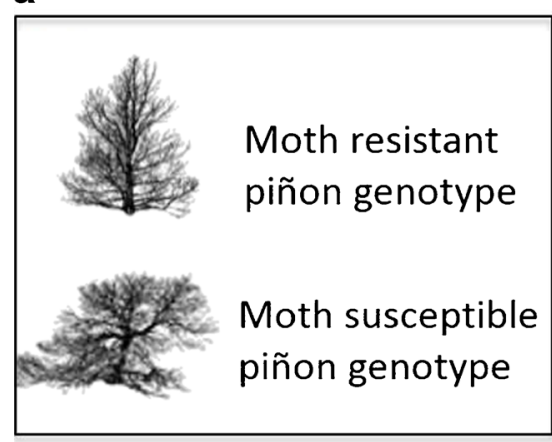

b

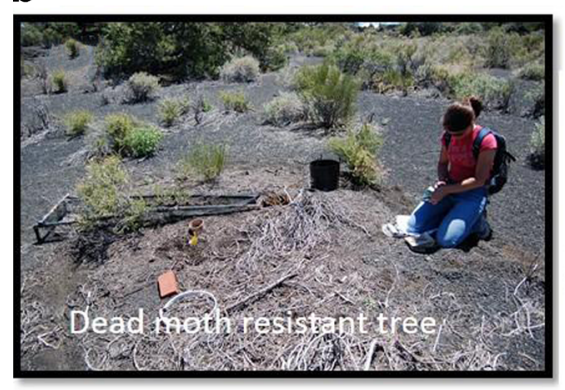

c

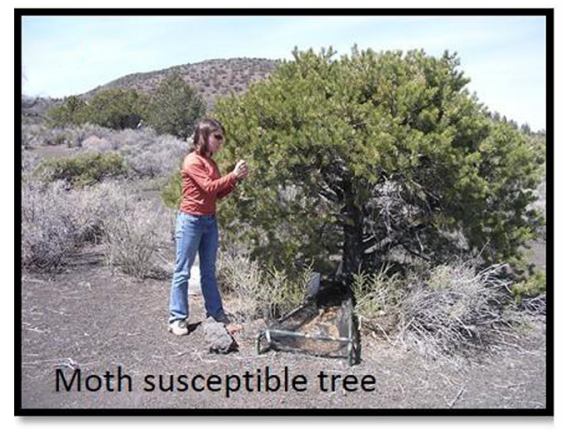

Fig. 4 Piñon mortality based on genotype and ecosystem effects. Moth susceptible trees have a visibly stunted growth form as compared to moth resistant trees (a). However, moth resistant trees ultimately died in greater numbers (b) than moth susceptible trees following a drought (c); In panel $\mathbf{b}$, only branches of dead tree and small stem are visible in a location that previously had a full grown live tree (such as panel c). The map on top right (d), depicts the pre-mortality distribution of moth-susceptible (33\% of local population) and moth-resistant piñons (67\% of local population) on a piñon-juniper landscape (see panel (a) for key to plant types). The map labeled "after" (e) depicts an altered distribution (50\%:50\%)

Subsequent greenhouse experiments support the hypothesis that plant genetics determines which ectomycorrhizal fungal community a seedling will acquire, and also show that these differences in fungal d

\section{Piñon-juniper landscape before drought}

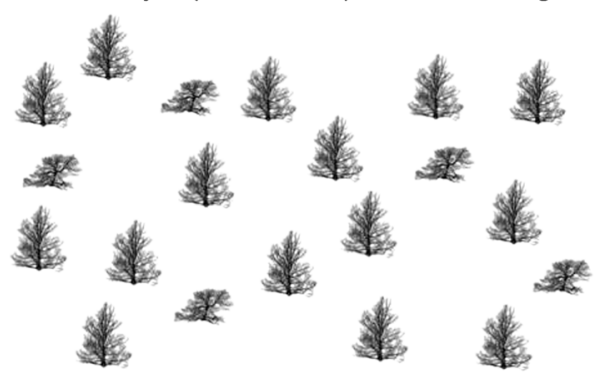

e

Piñon-juniper landscape after droughtinduced mortality

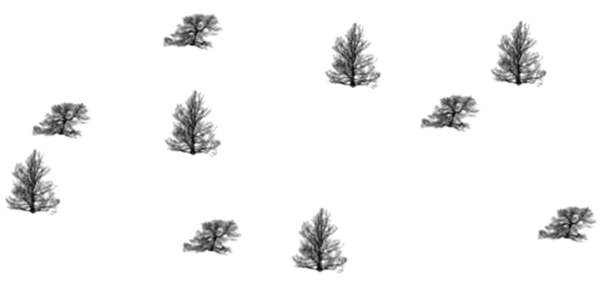

f

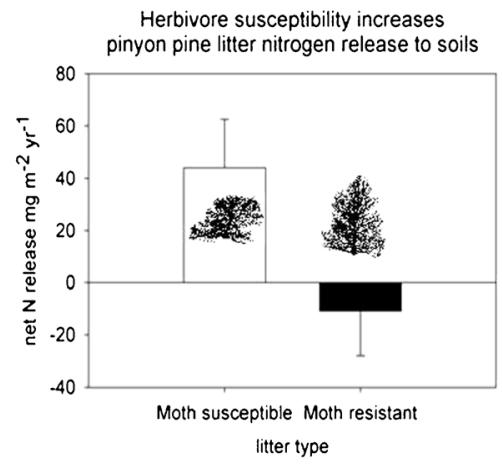

due to differential mortality of piñon genotypes based on herbivore-susceptibility. This differential mortality will likely have large impacts on nutrient and carbon accumulation and cycling at the ecosystem scale due to findings such as those in panel (f). In panel $\mathbf{f}$, we show that differences in canopy architecture and chemistry between susceptible and resistant trees extend to produce differences in impacts on net nitrogen release from litter to soils. Susceptible genotypes release nitrogen to the soil but resistant genotypes immobilize soil nitrogen, resulting in different soil nitrogen fluxes due to herbivore susceptibility. Error bars represent + one standard error

communities influence seedling performance under drought conditions (Gehring et al. unpublished data). Taken together, these data demonstrate that intraspecific genetic variation in $P$. edulis influences climate change 
response through trade-offs between herbivore resistance and drought tolerance that appear to be mediated by soil fungal community composition.

These complex relationships between drought, plant genotype, and soil organisms are likely to alter the structure and function of pinyon-juniper woodlands in the long-term. If the southwestern US continues its transition to a more arid climate as predicted (e.g., Seager et al. 2007), resistant trees and their associated ectomycorrhizal fungi are likely to continue to be selected against, potentially leading to a positive feedback for the persistence of herbivore susceptible trees. Evidence for this hypothesis includes data showing that productivity (and hence $\mathrm{C}$ uptake) of resistant trees exceeded that of susceptible trees by approximately $15 \%$ for the 10 years prior to the current drought period. This pattern reversed as conditions have dried; the productivity of susceptible trees has exceeded that of resistant trees approximately $25 \%$ during the first 10 years of drought (Gehring et al. unpublished data). Dominance across the landscape by herbivore susceptible trees is likely to influence ecosystem $\mathrm{N}$ dynamics because moth herbivory alters the architecture and litter chemistry of susceptible trees. As a result of these changes, susceptible trees release $\mathrm{N}$ to the soil while resistant genotypes immobilize soil N, resulting in different soil $\mathrm{N}$ fluxes (Fig. 4; Classen et al. 2007).

The patterns observed in piñon-juniper woodlands may be broadly relevant; drought-related tree mortality is well documented throughout the western US (Van Mantgem et al. 2009), and trees from diverse ecosystems across the world are predicted to be highly vulnerable to drought (Choat et al. 2012). This example highlights that the influences of tree genetics and climate change selection on ecosystem function is only understandable when considering genetically-based traits related to belowground mutualisms, productivity/C allocation, and litter chemistry in synchrony.

\section{Conclusions, hypotheses and research approaches}

Climatic change is already profoundly shaping communities and ecosystems. We argue that genetically-based knowledge of the soil-plant interface may play an important role in understanding and mitigating the ecological and evolutionary effects of climate change on soils. Four findings are central to this argument. First, intraspecific variation exists in foundation plant species whereby different genotypes vary in key functional traits (i.e. productivity/C allocation, tissue chemical quality, water-use, and rhizosphere associations) that affect soil $\mathrm{C}$ flux, litter decomposition, and soil nutrient cycling. Collectively, these traits create a specific multivariate phenotype, which affects the associated soil community and soil function. Second, in some systems it has been demonstrated that different genotypes support different soil microbial communities, which feed back to affect plant performance and survival. If widespread, this has far-ranging implications for geneticallybased plant soil interactions and microbial communities (Bever et al. 1997; Lankau et al. 2011). Third, climate change is an agent of selection in which some plant genotypes and their microbial communities (e.g. drought tolerant organisms) are favored, while others are selected against. Fourth, climate selection on microbial communities (both directly and indirectly; Fig. 1) affects plant performance and survival. Thus, genetically-based feedbacks at the plant-soil interface are central to understanding plants and their soil responses to changing climatic conditions.

If these findings are broadly general, two overarching hypotheses emerge. First, climate change, as an agent of selection on foundation plant species and their microbial communities, will cause significant changes in soil processes and the plant-soil interface. Thus, even if a foundation species retains its overall dominant position on the landscape, changes in the genetic structure of plant populations due to selection arising from climate change (i.e. evolution) will still occur, resulting in shifts in their associated communities and ecosystem processes such as $\mathrm{C}$ feedbacks. Second, the combined and interactive contributions of key functional plant traits can be quantified and shown to shift in response to selection resulting from climate change. Because important plant traits are defined by few to many genes (Kessler and Baldwin 2006; Mackay et al. 2009), we expect that genetic by biotic and abiotic environment interactions will have quantifiable effects. These hypotheses become central for understanding and predicting the ecological and evolutionary consequences of climate change on the plant-soil interface.

A combination of new and old approaches can be used to test these hypotheses. First, common gardens are a fundamental tool to partition genetic and environmental components to the effects of plants on soils. Replicated common gardens planted across the landscape have been successful in defining the level of adaptation to local 
climate and soil conditions (e.g. O’Neill et al. 2008). Nevertheless, these gardens have rarely been utilized in a community context to evaluate genetically-based plant interactions with the soil microbial community and their effects on soil processes. By establishing experimental gardens with the same replicated plant genotypes and different soil inocula (e.g. Garbaye and Churin 1997; Ortega et al. 2004; Allen et al. 2005; Smith et al. 2012) arrayed along elevation gradients (a surrogate of climate as described above; e.g. the Populus example), researchers can experimentally evaluate the effects of plant genotype, soil communities, and environment on soil processes.

Second, long-term studies in common gardens and in the wild are needed that follow soil processes and their interactions with other community members associated with individual plant genotypes. For example, in a 2 year study Classen et al. (2013) initially found that herbivory on insect resistant and susceptible tree genotypes did not affect litterfall-C inputs and soil C-efflux rates. However, when the study was expanded over 3654 years, herbivory on susceptible trees was shown to slow soil $\mathrm{C}$ and $\mathrm{N}$ accumulation by $111 \%$ and $96 \%$, respectively relative to resistant trees. Thus, the change in the associated plant-soil phenotype of individual tree genotypes differed and was highly dependent on time $\times$ genotype $\times$ species interactions. As foundation species and their interactions with other species play a prominent role in soil development, long-term studies are needed to identify climate triggered changes in the trajectory of the plant-soil interface.

Third, models incorporating genetically-based functional traits will add an important evolutionary-based perspective that is currently lacking in most dynamic global vegetation models. Because plant productivity has a strong genetic component that differs greatly among populations (O’Neill et al. 2008), models incorporating population variation in productivity are more accurate in predicating the response of plant population responses to climate change (Wang et al. 2010) as well as the responses of their arthropod and mycorrhizal communities (Ikeda et al. 2014), than models that do not include genetically-based functional traits. Because productivity and $\mathrm{C}$ allocation have clear implications for soil function, coupling the above models to better incorporate trait distributions with soil process models may lead to better predictions of how climate driven population changes will alter climate influenced processes such as $\mathrm{C}$ feedbacks to the atmosphere. Further, new modeling approaches that incorporate interactions among plant and microbial traits as well plant-soil feedbacks may also improve our predictions of how ecosystems will be structured and how they will function under global change (Schweitzer et al. 2013).

Fourth, because genetic manipulations demonstrate how genes in plants can affect whole communities of organisms, similar studies can tell us much about the genetic basis of the plant-soil interface. For example, when defense genes for nicotine were silenced in wild tobacco, both the herbivore and the pollinator community shifted (Kessler and Baldwin 2006 and references therein). Similarly, using the same genetic lines developed for commercial production in managed systems, soil scientists can examine the role of specific plant genes and traits that define plant-soil phenotypes. Because these plants have the same background genetics as the wild type, researchers can be confident that changes in the soil microbial community or ecosystem processes are due to the traits expressed by the identified genes. Genomics approaches may allow researchers working with foundation species to determine when high belowground $\mathrm{C}$ allocation genes are present. In another case, Populus has been genetically modified for $45 \%$ lower lignin production to facilitate the production of biofuels and genetically modified microbes are being sought to further increase yield (review by Sannigrahi et al. 2010). Plots of these trees could be used to examine the effects of altered wood chemistry to soil dynamics and plant-soil feedbacks. Such assessments could unambiguously link genes to the plant-soil phenotype, allowing researchers to understand the mechanisms behind the patterns.

In summary, the evolution of the plant-soil phenotype in response to climate change requires a new level of interdisciplinary integration that promises a better understanding of interactions, as well as real solutions to climatic change. Genetically-based responses of plants to climate change may involve multivariate shifts in plant traits, and both effects on, and reactions to soil communities. Explicit recognition of multivariate traits and soil microbial interactions at the genetic level should accelerate genes-to-ecosystems research at the plant-soil interface in natural ecosystems. To address these ideas, diverse experimental approaches that integrate common gardens, long-term studies, and genetic mechanisms can tell us much about the ecology and 
evolution of the plant-soil phenotype in response to climate change.

Acknowledgments This work funded by the Science Foundation of Arizona, National Science Foundation grants DEB0816675 and DEB0236204, National Science Foundation Frontiers in Biological Research grant DEB-0425908, National Science Foundation Major Research Instrumentation grant DBI-1126840, Bureau of Reclamation grant CESU-06FC300025, and sabbatical funding to DGF from The Evergreen State College. We especially thank Carri J. LeRoy, Joe Bailey, The Evergreen Field and Ecosystem Ecology Laboratory, Randy Bangert, Gina Wimp, and Adam Langley for helpful comments and contributions. We also thank Abir Biswas for a very helpful pre-review of the final manuscript, and Mathew Smith for helpful suggestions on process during the initial drafts.

\section{References}

Aitken SN, Yeaman S, Holliday JA, Wang T, Curtis-McLane S (2008) Adaptation, migration or extirpation: climate change outcomes for tree populations. Evol Appl 1:95-111

Allen MF, Allen EB, Go A (2005) Effects of mycorrhizae and nontarget organisms on restoration of a seasonal tropical forest in Quintana Roo, Mexico: factors limiting tree establishment. Restor Ecol 13:325-333

Alsos IG, Ehrich D, Thuiller W, Eidesen PB, Tribsch A, Schönswetter P, Lagaye C, Taberlet P, Brochmann C (2012) Genetic consequences of climate change for northern plants. Proc R Soc B 279:2042-2051

Antoninka A, Wolf JE, Bowker M, Classen AT, Johnson NC (2009) Linking above and belowground responses to global change at community and ecosystem scales. Global Change Biol 15:914-929

Asner GP, Archer SA, Hughes RF, Ansley JN, Wessman CA (2003) Net changes in regional woody vegetation cover and carbon storage in North Texas rangelands, 1937-1999. Global Change Biol 9:316-335

Avolio M, Beaulieu J, Smith MD (2013) Genetic diversity of a dominant $\mathrm{C} 4$ grass is altered with increased precipitation variability. Oecologia 171:571-581

Bailey JK, Wooley SC, Lindroth RL, Whitham TG (2006) Importance of species interactions to community heritability: a genetic basis to trophic-level interactions. Ecol Lett 9:78-85

Bardgett RD, Manning P, Morriën E, De Vries FT (2013) Hierarchical responses of plant-soil interactions to climate change: consequences for the global carbon cycle. J Ecol 101:334-343

Bellgard SE, Williams SE (2011) Response of Mycorrhizal diversity to current climatic changes. Diversity 3:8-90

Bever J, Westover K, Antonovics J (1997) Incorporating the soil community into plant population dynamics: the utility of the feedback approach. J Ecol 85:561-573

Binkley D, Giardina C (1998) Why trees affect soils in temperate and tropical forests: the warp and woof of tree/soil interactions. Biogeochemistry 42:89-106
Blankenship JC, Niklaus PA, Hungate BA (2011) A meta-analysis of responses of soil biota to global change. Oecologia 165: 553-565

Breshears DD, Huxman TE, Adams HD, Zou CB, Davison JE (2008) Vegetation synchronously leans upslope as climate warms. Proc Natl Acad Sci 105:11591-11592

Bressan M, Roncato M-A, Bellvert F, Comte G, el Zahar HF, Achouak W, Berge O (2009) Exogenous glucosinolate produced by Arabidopsis thaliana has an impact on microbes in the rhizosphere and plant roots. ISME J 3:1243-1257

Breza L, Souza L, Sanders NJ, Classen AT (2012) Within and between population variation in plant traits predicts ecosystem functions associated with a dominant plant species. Ecol Evol 2:1151-1161

Castro HF, Classen AT, Austin EE, Norby RJ, Schadt CW (2010) Soil microbial community responses to multiple experimental climate change drivers. Appl Environ Microbiol 76:999-1007

Chapin FS III (1980) The mineral nutrition of wild plants. Annu Rev Ecol Syst 11:233-260

Chapman SK, Hart SC, Cobb NS, Whitham TG, Koch GW (2003) Herbivory increases litter quality and decomposition: an extension of the acceleration hypothesis. Ecology 84:28672876

Chapman SK, Schweitzer JA, Whitham TG (2006a) Herbivory differentially alters plant litter dynamics of evergreen and deciduous trees. Oikos 114:566-574

Chapman SK, Langley JA, Hart SC, Koch GW (2006b) Plants actively control nitrogen cycling: uncorking the microbial bottleneck. New Phytol 169:27-34

Choat B, Jansen S, Brodribb TJ, Cochard H, Delzon S, Bhaskar R, Bucci SJ, Field TS, Gleason SM, Hacke UG, Jacobsen AL, Lens F, Maherali H, Martinez-Vilalta J, Mayr S, Mencuccini M, Mitchell PJ, Nardini A, Pittermann J, Pratt RB, Sperry JS, Westoby M, Wright IJ, Zanne AE (2012) Global convergence in the vulnerability of forests to drought. Nature 491:752-755

Churma DJ, Anderson PD, Howe GT, Harrington CA, Halofsky JE, Peterson DL, Shaw DC, St. Clair JB (2011) Forest responses to climate change in the northwestern United States: ecophysiological foundations for adaptive management. For Ecol Manag 261:1121-1142

Classen AT, DeMarco J, Hart SC, Whitham TG, Cobb NS, Koch GW (2006) Impacts of herbivorous insects on decomposer communities during the early stages of primary succession in a semi-arid woodland. Soil Biol Biochem 38:972-982

Classen AT, Chapman SK, Whitham TG, Hart SC, Koch GW (2007) Genetic-based plant resistance and susceptibility traits to herbivory influence needle and root litter nutrient dynamics. J Ecol 95:1181-1194

Classen AT, Chapman SK, Whitham TG, Hart SC, Koch GW (2013) Long-term insect herbivory slows soil development in an arid ecosystem. Ecosphere. doi:10.1890/ES12-00411.1

Cornelissen JHC, Aerts R, Cerabolini B, Werger MJA, van der Heijden MGA (2001) Carbon cycling traits of plant species are linked with mycorrhizal strategy. Oecologia 129:611-619

Courty PE, Buée M, Diedhiou AG, Frey-Klett P, Le Tacon F, Rineau F, Turpault MP, Uroz S, Garbaye J (2010) The role of ectomycorrhizal, communities in forest ecosystem processes: new perspectives and emerging concepts. Soil Biol Biochem 42:679-698

Crowther TM, Bradford MA (2013) Thermal acclimation in widespread heterotrophic soil microbes. Ecol Lett 16:469-477 
Crutsinger GM, Collins MD, Fordyce JA, Gompert Z, Nice CC, Sanders NJ (2006) Plant genotypic diversity predicts community structure and governs an ecosystem process. Science 313:966-968

Crutsinger GM, Sanders NJ, Classen AT (2009) Comparing intraand inter-specific effects on litter decomposition in an oldfield ecosystem. Basic Appl Ecol 10:535-543

Davis MB, Shaw RG, Etterson JR (2005) Evolutionary responses to changing climate. Ecology 86:1704-1714

Dayton PK (1972) Toward an understanding of community resilience and the potential effects of enrichments to the benthos at McMurdo Sound, Antarctica. In: Parker $\mathrm{BC}$ (ed) Proceedings of the colloquium on conservation problems. Allen Press, Lawrence, pp 81-96

Evans S, Wallenstein MD (2012) Soil microbial community response to drying and rewetting stress: do microorganisms adapt to altered rainfall timing? Biogeochemistry 109:101-116

Fischer DG, Hart SC, Whitham TG, Martinsen GD, Keim P (2004) Ecosystem implications of genetic variation in water-use of a dominant riparian tree. Oecologia 139:188197

Fischer DG, Hart SC, Rehill BJ, Lindroth RL, Keim P, Whitham TG (2006) Do high-tannin leaves require more roots? Oecologia 149:668-675

Fischer DG, Hart SC, LeRoy CJ, Whitham TG (2007) Variation in belowground carbon fluxes along a Populus hybridization gradient. New Phytol 176:415-425

Fischer DG, Hart S, Schweitzer J, Selmants P, Whitham T (2010) Soil nitrogen availability varies with plant genetics across diverse river drainages. Plant Soil 331:391-400

Fournier-Level A, Korte A, Cooper MD, Cooper MD, Nordborg M, Schmitt J, Wilczek AM (2011) A map of local adaptation in Arabidopsis thaliana. Science 334:86-89

Fussmann GF, Loreau M, Abrams PA (2007) Eco-evolutionary dynamics of communities and ecosystems. Funct Ecol 21: 465-477

Garbaye J, Churin J (1997) Growth stimulation of young oak plantations inoculated with the ectomycorrhizal fungus PaxiZZus invohtus with special reference to summer drought. For Ecol Manag 98:221-228

Garrity SR, Allen CD, Brumby SP, Grangodagamage C, McDowell NG, Cai DM (2013) Quantifying tree mortality in a mixed species woodland using multitemporal high spatial resolution satellite imagery. Remote Sens Environ 129:54-65

Gehring CA, Whitham TG (1991) Herbivore-driven mycorrhizal mutualism in insect-susceptible pinyon pine. Nature 353 : $556-557$

Gehring CA, Mueller R, Whitham TG (2006) Environmental and genetic effects on the formation of ectomycorrhizal and arbuscular mycorrhizal associations in cottonwoods. Oecologia 149:158-164

Gitlin AR, Sthultz CM, Bowker MA, Stumpf S, Paxton KL, Kennedy K, Munoz A, Bailey JK, Whitham TG (2006) Mortality gradients within and among dominant plant populations as barometers of ecosystem change during extreme drought. Conserv Biol 20:1477-1486

Grady KC, Ferrier SM, Kolb TE, Hart SC, Allan GJ, Whitham TG (2011) Genetic variation in productivity of foundation riparian species at the edge of their distribution: implications for restoration and assisted migration in a warming climate. Global Change Biol 17:3724-3735
Grady KC, Laughlin DC, Ferrier SM, Kolb TE, Hart SC, Allan GJ, Whitham TG (2013) Conservative leaf economic traits correlate with fast growth of genotypes of a foundation riparian species near the thermal maximum extent of its geographic range. Funct Ecol. doi:10.1111/1365-2435.12060

Gray SB, Classen AT, Kardol P, Yermakov Z, Miller MA (2011) Multiple climate change factors interact to alter soil microbial community structure in an old-field ecosystem. Soil Sci Soc Am J 75:2217-2226

Hancock AM, Brachi B, Faure N, Horton MW, Jarymowycz LB, Sperone FG, Toomajian C, Roux F, Bergelson J (2011) Adaptation to climate across the Arabidopsis thaliana genome. Science 334:83-86

Hardie DC, Hutchings JA (2010) Evolutionary ecology at the extremes of species ranges. Environ Rev 18:1-20

Heinemeyer A, Hartley IP, Evans SP, De la Fuente JAC, Ineson P (2007) Forest soil CO2 flux: uncovering the contribution and environmental responses of ectomycorrhizas. Global Change Biol 13:1786-1797

Hoeksema JD, Classen AT (2012) Is plant genetic control of ectomycorrhizal communities an untapped source of stable soil carbon in managed forests? Plant Soil 359:197-204

Horton JL, Hart SC (1998) Hydraulic lift: a potentially important ecosystem process. Tree 13:232-235

Hughes AR, Stachowicz JJ (2009) Ecological impacts of genotypic diversity in the clonal seagrass, Zostera marina. Ecology 90:1412-1419

Hughes AR, Inouye BD, Johnson MTJ, Underwood N, Vellend M (2008) Ecological consequences of genetic diversity. Ecol Lett 11:609-623

Iason G, Moore B, Lennon J, Stockan J, Osler G, Campbell C, Sim D, Beaton J, Russell J (2012) Plant secondary metabolite polymorphisms and the extended chemical phenotype. In: Iason GR, Dicke M, Hartley SE (eds) The ecology of plant secondary metabolites: from genes to global processes. Cambridge University Press, New York, pp 247-268

Ikeda DH, Bothwell HM, Lau MK, O’Neill GA, Grady KC, Whitham TG (2014) A genetics-based universal community transfer function for predicting the impacts of climate change on future communities. Funct Ecol. doi:10.1111/1365-2435. 12151

Kardol P, Cregger MA, Campany CE, Classen AT (2010) Soil ecosystem functioning under climate change: plant species and community effects. Ecology 91:767-781

Keenan T, Hollinger D, Bohrer G, Dragoni D, Munger JW, PeterSchmid H, Richardson AD (2013) Increase in forest wateruse efficiency as atmospheric carbon dioxide concentrations rise. Nature 499:324-328

Kessler D, Baldwin IT (2006) Making sense of nectar scents: the effects of nectar secondary metabolites on floral visitors of Nicotiana attenuata. Plant J 49:840-854

Kipfer T, Wohlgemuth T, van der Heijden MGA, Ghazoul J, Egli S (2012) Growth response of drought-stressed Pinus sylvestris seedlings to single- and multi-species inoculation with ectomycorrhizal fungi. PLoS ONE 7:e35275. doi:10.1371/ journal.pone.0035275

Knight CA, Vogel H, Kroymann J, Shumate A, Witsenboer H, Mitchell-Olds T (2006) Expression profiling and local adaptation of Boecheraholboellii populations for water use efficiency across a naturally occurring water stress gradient. Mol Ecol 15:1229-1237 
Labbe J, Jorge V, Kohler A, Vion P, Marcais B, Bastien C, Tuskan GA, Martin F, Le Tacon F (2011) Identification of quantitative trait loci affecting ectomycorrhizal symbiosis in an interspecific F1 poplar cross and differential expression of genes in ectomycorrhizas of the two parents: Populus deltoides and Populus trichocarpa. Tree Genet Genomes 7:617-627

Langley JA, Chapman SK, Hungate BA (2006) Ectomycorrhizal colonization slows root decomposition: the post mortem fungal legacy. Ecol Lett 9:955-959

Lankau RA (2011) Genetic variation in allelochemistry determines an invasive species' impact on soil microbial communities. Oecologia 165:453-463

Lankau RA, Wheeler E, Bennett AE, Strauss SY (2011) Plant-soil feedbacks contribute to an intransitive competitive network that promotes both genetic and species diversity. J Ecol 99: 176-185

Lau JA, Lennon JT (2011) Evolutionary ecology of plant-microbe interactions: soil microbial structure alters selection on plant traits. New Phytol 192:215-224

Lau JA, Lennon JT (2012) Rapid responses of soil microorganisms improve plant fitness in novel environments. Proc Natl Acad Sci 109:14058-14062

Lavergne S, Mouquet N, Thuiller W, Ronce O (2010) Biodiversity and climate change: integrating evolutionary and ecological responses of species and communities. Annu Rev Ecol Evol Syst 41:321-350

Lehto T, Zwiazek JJ (2011) Ectomycorrhizas and water relations of trees: a review. Mycorrhiza 21:71-90

LeRoy CJ, Whitham TG, Wooley SC, Marks JC (2007) Withinspecies variation in foliar chemistry influences leaf-litter decomposition in a Utah river. J N Am Benthol Soc 26: 426-438

Liu X, Liang M, Etienne RS, Wang Y, Staehelin C, Yu S (2012) Experimental evidence for a phylogenetic Janzen-Connell effect in a subtropical forest. Ecol Lett 15:111-118

Lloret F, Peñuelas J, Prieto P, Llorens L, Estiarte M (2009) Plant community changes induced by experimental climate change: seedling and adult species composition. Perspect Plant Ecol 11:53-63

Lojewski NR, Fischer DG, Bailey JK, Schweitzer JA, Whitham TG, Hart SC (2009) Genetic basis of aboveground productivity in two native Populus species and their hybrids. Tree Physiol 29:1133-1142

Lojewski NR, Fischer DG, Bailey JK, Schweitzer JA, Whitham TG, Hart SC (2012) Genetic components to belowground carbon fluxes in a riparian forest ecosystem: a common garden approach. New Phytol 195:631-639

Lundberg DS, Lebeis SL, Paredes SH, Yourstone S, Gehring J, Malfatti S, Tremblay J, Engelbrektson A, Kunin V, del Rio TG, Edgar RC, Eickhorst T, Ley RE, Hugenholtz P, Tringe SG, Dangl JL (2012) Defining the core Arabidopsis thaliana root microbiome. Nature 488:86-90

Mackay TFC, Stone EA, Ayroles JF (2009) The genetics of quantitative traits: challenges and prospects. Nat Rev Genet 10:565-577

Madritch MD, Hunter MD (2003) Intraspecific litter diversity and nitrogen deposition affect nutrient dynamics and soil respiration. Oecologia 136:124-128

Madritch MD, Lindroth RL (2011) Soil microbial communities adapt to genetic variation in leaf litter inputs. Oikos 120: 1696-1704
Madritch M, Donaldson JR, Lindroth RL (2006) Genetic identity of Populus tremuloides litter influences decomposition and nutrient release in a mixed forest stand. Ecosystems 9:528537

Madritch MD, Greene SL, Lindroth RL (2009) Genetic mosaics of ecosystem functioning across aspen-dominated landscapes. Oecologia 160:119-127

Matthews B, Narwani A, Hausch S et al (2011) Toward an integration of evolutionary biology and ecosystem science. Ecol Lett 14:690-701

McCarthy-Neumann S, Ibanez I (2012) Tree range expansion may be enhanced by escape from negative plant-soil feedbacks. Ecology 93:2637-2649

McDowell N, Pockman WT, Allen CD, Breshears DD, Cobb N, Kolb T, Plaut J, Sperry J, West A, Williams DG, Yepez EA (2008) Mechanisms of plant survival and mortality during drought: why do some plants survive while others succumb to drought? New Phytol 178:719-739

Micallef SA, Shiaris MP, Colon-Carmona A (2009) Influence of Arabidopsis thaliana accessions on rhizobacterial communities and natural variation in root exudates. J Exp Bot 60 : 1729-1742

Mopper S, Mitton J, Whitham TG, Cobb NS, Christensen KM (1991) Genetic differentiation and heterozygosity in pinyon pine associated with herbivory and environmental stress. Evolution 45:989-999

Mueller RC, Scudder CM, Porter ME, Trotter RT, Gehring CA, Whitham TG (2005) Differential tree mortality in response to severe drought: evidence for long-term vegetation shifts. J Ecol 93:1085-1093

Naiman RJ, Décamps H (1997) The ecology of interfaces: riparian zones. Annu Rev Ecol Syst 28:621-658

Norberg J, Urban MC, Vellend M, Klausmeier CA, Loeuille N (2012) Eco-evolutionary responses of biodiversity to climate change. Nat Clim Chang 2:747-751

Norby RJ, Zak DR (2011) Ecological Lessons from Free-Air CO2 Enrichment (FACE) experiments. Annu Rev Ecol Evol Syst 42:181-203

O’Neill GA, Hamann A, Wang T (2008) Accounting for population variation improves estimates of the impact of climate change on species' growth and distribution. J Appl Ecol 45: 1040-1049

Ortega U, Duñabeitia M, Menendez S et al (2004) Effectiveness of mycorrhizal inoculation in the nursery on growth and water relations of Pinus radiata in different water regimes. Tree Physiol 24:65-73

Parmesan C (2006) Ecological and evolutionary responses to recent climate change. Annu Rev Ecol Evol Syst 37:637-669

Peiffer JA, Spor A, Koren O, Jin Z, Tringe SG, Dangl JL, Buckler ES, Ley RE (2013) Diversity and heritability of the maize rhizosphere microbiome under field conditions. PNAS 110: $6548-6553$

Pregitzer CC, Bailey JK, Schweitzer JA (2013) Genetic by environment interactions affect plant-soil linkages. Ecol Evol 3: 2322-2333

Rasse DP, Rumpel C, Dignac MF (2005) Is soil carbon mostly root carbon? Mechanisms for a specific stabilization. Plant Soil 269:341-356

Rehfeldt GE, Ying CC, Spittlehouse DL, Hamilton DA (1999) Genetic responses to cli- mate in Pinus contorta: niche breadth, climate change, and reforestation. Ecol Monogr 69:375-407 
Rehill BJ, Whitham TG, Martinsen GD, Schweitzer JA, Bailey JK, Lindroth RL (2006) Developmental trajectories in cottonwood phytochemistry. J Chem Ecol 32:2269-2285

Rowntree JK, Shuker DM, Preziosi RF (2011) Forward from the crossroads of ecology and evolution. Phil Trans R Soc B 366: $1322-1328$

Sannigrahi P, Ragauskas AJ, Tuskan GA (2010) Poplars as a feedstock for biofuels: a review of compositional characteristics. Biofuels Bioprod Bioref 4:209-226

Schimel J, Balser T, Wallenstein M (2007) Microbial stressresponse physiology and its implications for ecosystem function. Ecology 88:1386-1394

Schoener TW (2011) The newest synthesis: understanding the interplay of evolutionary and ecological dynamics. Science 331:426-429

Schweitzer JA, Bailey JK, Rehill BJ, Martinsen GD, Hart SC, Lindroth RL, Keim P, Whitham TG (2004) Genetically based trait in a dominant tree affects ecosystem processes. Ecol Lett 7:127-134

Schweitzer JA, Bailey JK, Fischer DG, LeRoy CJ, Lonsdorf EV, Whitham TG, Hart SC (2008a) Soil microorganism-plant interactions; heritable relationship between plant genotype and associated microorgansims. Ecology 89:773-781

Schweitzer JA, Madritch MD, Bailey JK, LeRoy CJ, Fischer DG, Rehill BJ, Lindroth RL, Hagerman AE, Wooley SC, Hart SC, Whitham TG (2008b) From genes to ecosystems: the genetic basis of condensed tannins and their role in nutrient regulation in a Populus model system. Ecosystems 11:1005-1020

Schweitzer JA, Fischer DG, Rehill BJ, Wooley SC, Woolbright SA, Lindroth RL, Whitham TG, Zak DR, Hart SC (2011) Forest gene diversity influences the composition and function of soil microbial communities. Popul Ecol 53:35-46

Schweitzer JA, Madritch MD, Felker-Quinn E, Bailey JK (2012) From genes to ecosystems: how plant genetics links aboveand below-ground processes. In: Wall D (ed) Soil ecology and ecosystem services. Oxford University Press, Oxford, pp $82-98$

Schweitzer JA, Juric I, van de Voorde TFJ, Clay K, van der Putten WH, Bailey JK (2013) Are there evolutionary consequences of plant-soil feedbacks along soil gradients? Funct Ecol. doi: 10.1111/1365-2435.12201

Seager R, Ting M, Held I, Kushnir Y, Lu J, Vecchi G, Huang H-P, Harnik N, Leetmaa A, Lau N-C, Li C, Velez J, Naik N (2007) Model projections of an imminent transition to a more arid climate in southwestern North America. Science 316:11811184

Sexton JP, Strauss SY, Rice KJ (2011) Gene flow increase fitness at the warm edge of a species' range. Proc Natl Acad Sci 108: 11704-11709

Sharp ED, Sullivan PF, Steltzer H, Csank AZ, Welker JM (2013) Complex carbon cycle responses to multi-level warming and supplemental summer rain in the high Arctic. Global Change Biol. doi:10.1111/gcb.12149

Smith DS, Schweitzer JA, Turk P, Bailey JK, Hart SC, Shuster SM, Whitham TG (2012) Soil-mediated local adaptation alters seedling survival and performance. Plant Soil 352: 243-251

Souza L, Weston DJ, Sanders NJ, Karve A, Crutsinger GM, Classen AT (2011) Variation from individuals to ecosystems in the response to climatic warming: a test with Solidago altissima. Ecosphere 2:1-14
Sthultz CM, Gehring CA, Whitham TG (2009a) Deadly combination of genes and drought: increased mortality of herbivore-resistant trees in a foundation species. Glob Chang Biol 15:1949-1961

Sthultz CM, Whitham TG, Kennedy K, Deckert R, Gehring CA (2009b) Genetically-based susceptibility to herbivory influences the ectomycorrhizal fungal communities of a foundation tree species. New Phytol 184:657-667

Thuiller W, Albert C, Araujo MB, Berry PM, Cabeza M, Guisan A, Hickler T, Midgely GF, Paterson J, Schurr FM, Sykes MT, Zimmermann NE (2008) Predicting global change impacts on plant species' distributions: future challenges. Perspect Plant Ecol Evol Syst 9:137-152

Travers SE, Tang Z, Caragea D, Garrett KA, Hulbert SH, Leach JE, Bai J, Sahel A, Knapp AK, Fay PA, Nippert J, Schnable PS, Smith MD (2010) Variation in gene expression of Andropogon gerardii in response to altered environmental conditions associated with climate change. J Ecol 98:374 383

Treseder KK, Vitousek PM (2001) Potential ecosystem-level effects of genetic variation among populations of Metrosideros polymorpha from a soil fertility gradient in Hawaii. Oecologia 126:266-275

Van Mantgem PJ, Stephenson NL, Byrne JC et al (2009) Widespread increase of tree mortality rates in the western United States. Science 323:521-524

Velmala SM, Haapanen M, Rajala T, Taylor AFS, Pennanen T (2013) Genetic host-tree effects on the ectomycorrhizal community and root characteristics of Norway spruce. Mycorrhiza 23:21-33

Wallenstein MD, Hall EK (2011) A trait-based framework for predicting when and where microbial adaptation to climate change will affect ecosystem functioning. Biogeochemistry 109:35-47

Wang T, O’Neill GA, Aitken SN (2010) Integrating environmental and genetic effects to predict responses of tree populations to climate. Ecol Appl 20:153-163

Weinert N, Piceno Y, Ding GC, Meincke R, Heuer H, Berg G, Schloter M, Andersen G, Smalla K (2011) PhyloChip hybridization uncovered an enormous bacterial diversity in the rhizosphere of different potato cultivars: many common and few cultivar-dependent taxa. FEMS Microbiol Ecol 75:497-506

Whitham TG, Mopper S (1985) Chronic herbivory: impacts on architecture and sex expression of pinyon pine. Science 228 : 1089-1091

Whitham TG, Bailey JK, Schweitzer JA, LeRoy CJ, Fischer DG, Lonsdorf E, Shuster SM, Lindroth RL, Hart SC, Allan GJ, Gehring CA, Keim P, Potts BM, Woolbright S (2006) From genes to ecosystems: how genes structure communities and affect ecosystem processes. Nat Rev Genet 7:510-523

Whitham TG, Gehring CA, Lamit LJ, Wojtowicz T, Evans LM, Keith AR, Smith DS (2012) Community specificity: life and afterlife effects of genes. Trends Plant Sci 17:271-281

Wilczek AM, Burghardt LT, Cobb AR, Cooper MD, Welch SM, Schmitt J (2010) Genetic and physiological bases for phenological responses to current and predicted climates. Proc R Soc B 365:3129-3147

Wu Z, Dijkstra P, Koch GW, Hungate BA (2012) Biogeochemical and ecological feedbacks in grassland responses to warming. Nat Clim Chang 2:458-461 
Wullschleger SD, Weston DJ, Davis JM (2009) Populus responses to edaphic and climatic cues: emerging evidence from systems biology research. Crit Rev Plant Sci 28:368-374

Zancarini A, Mougel C, Voisin AS, Prudent M, Salon C, MunierJolain N (2012) Soil nitrogen availability and plant genotype modify the nutrition strategies of $M$. truncatula and the associated rhizosphere microbial communities. PLoS ONE 7:e47096

Zinke PJ (1962) The pattern of influence of individual forest trees on soil properties. Ecology 43:130-133 